\title{
Monika Szturcová
}

Uniwersytet Ostrawski w Ostrawie

monika.szturcova@email.cz

ORCID: 0000-0003-0581-0371

\section{Czesko-polskie pieśni pielgrzymkowe w drukach kramarskich z XVIII i XIX w.}

\section{Czech-Polish pilgrim songs in broadside ballads of 18 th and 19th century}

DOI: $10.12775 /$ LL.4.2021.004 | CC BY-ND 3.0 PL

ABSTRACT: The paper constitutes an analysis of Czech-Polish relations in the Polishand Czech-language pilgrim songs in the 18th-19th century. The main subject of the analysis is the select choice of pilgrim songs transferred from the Czech cultural context to the Polish and vice versa. The discussed texts allow the author to present new perspectives on possible research on broadside ballads and formulate a general approach to studying Polish-Czech culture transfer.

KEYWORDS: broadside ballad, pilgrim song, Czech-Polish 18-19th century relations

\section{Wstęp}

Badania czesko-polskich kontaktów literackich mają długą tradycję i poświęcono im bogatą literaturę naukową, zawierająca zarówno prace o charakterze ogólnym, dotyczące całych epok, jak też artykuły o węższym profilu oraz publikacje monograficzne. Ogólnie możemy stwierdzić, że temu zagadnieniu poświęcano uwage głównie w ramach tzw. literatury wysokiej, przy czym pierwszeństwo miały okresy romantyzmu i odrodzenia narodowego oraz wiek XX. Jak się zdaje, największym zainteresowaniem badaczy cieszyła się kwestia wpływu i oddziaływania polskich romantyków na czeską literaturę i kulturę (Sobotková 2002). Czescy i polscy badacze szczegółowo analizowali niezwykle istotne polskie 
wpływy na literaturę czeską okresu odrodzenia narodowego i całego XIX w. Jeśli chodzi o pieśni, uwaga koncentrowała się na relacjach w obszarze tematyki religijnej z XVI i XVII w. Na szereg paraleli między pieśniową twórczością polską i czeską zwrócili uwage Pavel Kosek, Tomáš Slavický i Marie Škarpová w przygotowanym przez siebie wydaniu pracy Jesličky Fridricha Bridela (Kosek, Slavický, Škarpová 2014). O tłumaczeniach pieśni Braci Czeskich na język polski oraz ich przenikaniu do polskich kancjonałów luterańskich pisał natomiast Jan Malura (2010).

Omawiając czesko-polskie związki kulturowe, trzeba zwrócić uwage na to, że kwestia kontaktów i wpływów w obszarze literatury kramarskiej do dzisiaj nie doczekała się systematycznej analizy. Szczytowy okres popularności druków kramarskich w Czechach i na Morawach przypadał na XVIII w. oraz pierwszą połowę XIX w. (Waliński 1975; Mętrak 2018). Na ziemiach czeskich zachowały się dziesiątki tysięcy tego typu publikacji, jednak zainteresowanie nimi było niewielkie i przez długie lata nie doceniano ich jako wartościowego źródła do poznania ówczesnej kultury druku i preferencji czytelniczych szerokich mas ludowych. Dopiero w ostatnim czasie mocno rozwijają się badania popularnych publikacji religijnych (Kafka 2008; Ivánek 2017), zwłaszcza druków związanych z fenomenem odpustów (Ivánek, Malura 2019; Ivánek, Malura, Olšovský, Schenková, Szturcová 2019).

W niniejszym artykule chciałabym zwrócić uwage na interesujące czesko-polskie paralele, które zauważyłam podczas badania pieśni kramarskich o tematyce religijnej ${ }^{1}$. Interesują mnie zwłaszcza wpływy, które miały znaczenie dla genezy konkretnych tekstów. Przenikanie pieśni religijnych między ziemiami czeskimi i polskimi ułatwiała bliskość językowa oraz pokrewieństwo kulturowe. Literatura kramarska upowszechniała się do pewnego stopnia podobnie jak literatura ludowa, tzn. obok druku istotna była tu również transmisja w formie ustnej. Można zatem w tym przypadku wykorzystać wyniki badań folklorystyki porównawczej. Zgodnie z jej ustaleniami, kiedy zjawisko folkloru przekracza

1 Artykuł powstał w ramach projektu SGSo2/FF/2020 „The borders and cultural transfers. Contributions to literary comparative studies” (Uniwersytet Ostrawski). Badania były prowadzone w latach 2015-2021 i objęły ponad 5 ooo pielgrzymkowych druków kramarskich z kolekcji w instytucjach czeskich (Národní knihovna v Praze, Knihovna Národního muzea v Praze, Regionální muzeum v Litomyšli, Etnologický ústav Akademie Věd ČR v Brně, Moravská zemská knihovna v Brně, Moravské zemské muzeum v Brně, Muzeum Vyškovska ve Vyškově, Muzeum Vysočiny v Jihlavě, Vlastivědná knihovna v Olomouci, Vlastivědné muzeum v Olomouci, Muzeum a galerie v Prostějově, Muzeum Komenského v Přerově, Muzeum regionu Valašsko ve Vsetíně, Muzeum Beskyd ve Frýdku-Místku, Muzeum Těšínska v Českém Těšíně, Ostravské muzeum, Slezské zemské muzeum v Opavě) oraz prawie 1500 druków kramarskich z kolekcji w instytucjach polskich (Biblioteka Narodowa w Warszawie, Biblioteka Uniwersytetu Warszawskiego, Biblioteka Jasnogórska w Częstochowie, Biblioteka Uniwersytetu Jagiellońskiego w Krakowie, Muzeum Etnograficzne im. Seweryna Udzieli w Krakowie, Biblioteka Śląska w Katowicach, Książnica Cieszyńska w Cieszynie). Warto dodać, że polskie druki z drukarń na Śląsku Cieszyńskim można odnaleźć także w niektórych czeskich kolekcjach druków kramarskich (Moravské zemské muzeum v Brně, Muzeum Beskyd ve Frýdku-Místku, Muzeum Těšínska v Českém Těšíně, Slezské zemské muzeum v Opavě). 
granicę etniczną między grupami spokrewnionymi językowo i kulturowo, wymiana przebiega w sposób bardzo zbliżony do tego, jaki ma miejsce wewnątrz tradycji narodowych, między poszczególnymi regionami etnograficznymi (Sirovátka 1996: 97-98).

Czesko-polskie paralele w zakresie pieśni ludowej zostały już zauważone i opisane przez wielu zbieraczy i badaczy. Polskie warianty wielu pieśni morawskich zanotował na ziemiach czeskich teolog František Sušil (1804-1868). Opublikował je w zbiorze Moravské národní písně (Sušil 1860), w którym odwoływał się do kilku ówczesnych zbiorów polskich pieśni ludowych. Uwagi Sušila uzupełniła później Helena Windakiewiczowa (1868-1956), która przygotowała katalog polsko-morawskich wariantów pieśniowych (Windakiewiczowa 1908). O przekładach na język polski czeskich pieśni religijnych, rozpowszechnianych w XIX w. za pośrednictwem druków kramarskich pisał także Stanisław Dobrzycki w pracy poświęconej czesko-polskim paralelom w pieśniach bożonarodzeniowych (Dobrzycki 1930). Zwracał on uwage na dwukierunkowe przejmowanie (tłumaczenia) popularnego repertuaru pieśniowego przez drukarnie na pograniczu czesko-polskim. Za cenny wkład w dyskusję nad tym zagadnieniem uznana może być również praca magisterska Michała Kałuży, poświęcona polskim pieśniom religijnym o czeskiej proweniencji, wykorzystywanym w okolicach Wodzisławia (Kałuża 1974). O przejmowaniu znanych tekstów religijnych między ziemiami czeskimi i polskimi pisał też Adam Nowak w pracy magisterskiej poświęconej niemiecko-polsko-czeskim tradycjom pieśniowym (Nowak 1996). Z kolei Kazimierz Dola (2004) podjął temat polskich, czeskich i niemieckich, a także łacińskich wariantów pieśni katolickich na pograniczu czesko-polskim.

\section{Czesko-polskie pieśni pielgrzymkowe w drukach kramarskich}

Podczas prowadzonych badań dotarłam do ponad 30 pieśni maryjnych posiadających zarówno czeską, jak i polską wersję językową. W kilku przypadkach natrafiłam na teksty przeznaczone dla tego samego miejsca pielgrzymkowego: Częstochowy, Wambierzyc oraz Kalwarii Zebrzydowskiej, które odwiedzane były również przez pielgrzymów z Czech. W dalszej części artykułu wybieram do szczegółowej analizy kilka przypadków, które są interesującym dokumentem procesu twórczego i mogą nam pomóc w jego wyjaśnieniu. Analizując teksty, będę śledzić liczbę zanotowanych wydań poszczególnych pieśni oraz warianty przeznaczone dla różnych miejsc pielgrzymkowych. Warto bowiem podkreślić, że zwykłym zjawiskiem - zarówno w środowisku czeskojęzycznym, jak i polskojęzycznym - była sytuacja, w której teksty pieśni traktowano niczym gotowe szablony, zmieniając w nich tylko nazwe miejsca pielgrzymkowego czy patrona, zgodnie z aktualnymi potrzebami. Należy dodać, że choć w próbach ustalenia kierunku tłumaczenia często pomaga nam charakterystyka językowa pieśni (teksty tłumaczone zwykle zawierają leksykalne oraz słowotwórcze bohemizmy i polonizmy), to w wielu przypadkach nie można jednoznacznie stwierdzić, która wersja była pierwotna. 
Pierwszy przykład stanowić będzie pieśń o incipicie „Vale, vale smutně dávám a odcházím z místa toho” ${ }^{2}$, której polskim odpowiednikiem jest: „Wale, wale smutne daję, odchodząc z miejsca tego"3. W środowisku czeskojęzycznym jest ona udokumentowana $\mathrm{w}$ drukach z pierwszej połowy XIX w., jednak pojawiała się jedynie w odniesieniu do Częstochowy i nie była zbytnio rozpowszechniona. W środowisku polskojęzycznym pojawia się w formie drukowanej od połowy XIX w. i oprócz Częstochowy w pojedynczych przypadkach odnosi się też do bliżej nieokreślonej Matki Boskiej Kalwaryjskiej

Pieśń ta przedstawia moment odejścia z miejsca pielgrzymkowego, kiedy to pątnik żegna się z Matką Boską i jej cudownym obrazem, ufając, że jemu i innym pielgrzymom dane będzie jeszcze tam w przyszłości wrócićs . Prosi on też o błogosławieństwo na droge i o szczęśliwy powrót do do domu:

1.

Vale, vale smutně dávám a odcházím z města toho, ó Královno nebe, země, od obrazu milostného, jak pak já tě opustit mám, neb se tobě odevzdávám, nemám v světě milejšího, nad tě uprrímnějšího ${ }^{6}$.
1.

Wale, wale smutne daję, odchodzę z miejsca tego, o Królowo nieba, ziemi, obrazu cudownego, jakóż ja cię odstąpić mam, bo cię, Panno, bardzo kocham, nie mam w świecie nic milszego, nad ciebie przyjemniejszego.

W obu wersjach wyraźne zaznaczają się motywy miłosne. Pielgrzym nikogo na świecie nie miłuje bardziej niż Matki Boskiej i nie może napatrzyć się na jej wizerunek. Kreuje się na wiernego służebnika Maryi, prosi ja, by wpisała go do swojego „rejestru” i ofiaruje jej swoje serce gorejące miłością.

8.

Nyní ti na znak milosti srdce mé ofěruji, k tvojim nohám odevzdávám, v celosti je daruji,

\section{7.}

Teraz ci na znak miłości serce me ofiaruję, pod twe nogi oddaję, wcale ci się daruję,

2 Píseñ o nejsvětější Panně Marii Častochovské. Odcházení z města svatého, 1. poł. XIX w., Těšín, Karel Procházka, Muzeum Beskyd, Frýdek-Místek, sygn. FM 12326.

3 Trzy pieśni. Pieśn o najświętszéj P. Maryi Częstochowskiéj, 2. poł. XIX w., Mikołów, Juliusz Nowacki, Biblioteka Śląska, Katowice, sygn. BŚ SLM 214593 I.

4 Np. Pieśń o Najświętszej Maryi Pannie Kalwaryjskiej. Gdy z miasta tego cudownego odchodza kompanie, 2. poł. XIX w., Frydek, Józef Orzeł, Biblioteka Narodowa, Warszawa, sygn. XX B 2 t. W tym przypadku, ponieważ jest to druk wydawany przez drukarnię rodziny Orlów we Frydku, możemy założyć, że mowa o Kalwarii Zebrzydowskiej.

5 Pieśni pielgrzymkowe zawierały elementy odnoszące się do poszczególnych etapów pielgrzymki, takich jak wędrówka, przybycie do sanktuarium, wskazówki dotyczące zachowania w sanktuarium, powitanie obrazu, pożegnanie, powrót do domu (Grochowski 2016: 93-114).

6 Wszystkie cytaty pochodzą z druków wskazywanych w pierwszym przywołaniu poszczególnych pieśni; liczby oznaczają numer strofy w danym druku. W cytatach zachowano oryginalną ortografię, łącznie z błędami typograficznymi. 
vtlač tvé jméno v srdci mojim a zapiš mne v lejstře tvojim, neb já chci tvé lásce žít i v tvé milosti umřít. wyraź imię w sercu mojém, a zapisz $\mathrm{w}$ rejestrze swoim, bo ja w twéj łasce chcę żyć i w miłości twéj umrzeć.

Pieśń czeska jest bezpośrednim i bardzo dosłownym przekładem z języka polskiego. Zawiera szereg niezgrabnych sformułowań, powstałych wskutek niedoskonałego tłumaczenia, np. fraza „choć w kąciku w tym kościele” powinna brzmieć po czesku „třeba v koutě v tom kostele”, a została przełożona jako „chot v kutě, tu v tvým kostele”. Pojawiają się też bezsensowne wyrazy prohne i prohnět', pochodzące prawdopodobnie z polskiego „pragnie”, czyli po czesku touží. Jeśli chodzi o inne nieścisłości, wymienić warto np. zastąpienie polskiego słowa „miłość” (cs. láska) czeskim słowem milost, czyli miłosierdzie. Pojawia się tu również szereg polonizmów, np. odjist (odejść), srdce přebija (serce przebija), pozvol že (pozwólże) czy ofěruji (ofiaruję). W czeskiej wersji tekstu amplifikowana została również cała czwarta zwrotka. Warto dodać, że zawiera on dodatkowo morawizmy takie jak ju, naša, tvojou czy svej.

Drugi przykład to para pieśni z Wambierzyc: „Vinšované jaro, ó nebeský ráji”7 i „Winszowana wiosno, o niebieski raju”. W obiegu czeskojęzycznym pieśń ta udokumentowana jest w formie drukowanej na początku XIX w., natomiast polska wersja pojawia się w drukach kramarskich $\mathrm{z}$ drugiej połowy XIX w. Czeski tekst posiada też starszy wariant z końca XVIII w. odnoszący się do Matki Boskiej Svatokopeckiej9, w którym nie ma zwrotek zawierających szczegółowy opis wędrówki przez kalwarię w Wambierzycach i przez Bardo, często odwiedzane przez pielgrzymów w powrotnej drodze z Wambierzyc.

Jest to obszerna pieśń pielgrzymkowa, rozpoczynająca się od motywu wiosny i śpiewu ptaków oraz zwrotu do Matki Boskiej:

1.

Vinšované jaro, ó nebeský ráji, ptáčkové nebeští, ptáčkové nebeští líbezně zpívají.

2.

Všecko se raduje, libě jarním čase, zezulička kuká, zezulička kuká přelíbezným hlasem.
1.

Winszowana wiosno, o niebieski raju, ptaszkowie niebiescy, ptaszkowie niebiescy wesoło śpiewają.

2.

Wszystko się raduje wdzięcznym wiosny czasem, słowiczek śpiewa i słowiczek śpiewa bardzo wdzięcznym głosem.

7 Nábožná píseñ k Panně Marii Svatovambeřické, 1. poł. XIX w., b. m., Regionální muzeum, Litomyšl, sygn. D-1234.

8 Cztery pieśni. Pieśń o Najświętszéj Pannie Maryi w Obrazie Albendorfskim cudownéj, 1862, Mikołów, Teofil Nowacki, Biblioteka Śląska, Katowice, sygn. BŚ SLM 212387 I.

9 Píseñ k Panně Marii Kopecké, poł. XIX w., Těšín, Karel Procházka, Muzeum Beskyd, Frýdek-Místek, sygn. FM 11378. 
W dalszych partiach tekstu pielgrzym rozmyśla o tym, że jest grzesznikiem, modli się i prosi Matkę Boską o wstawiennictwo u Chrystusa; później następuje szczegółowy opis miejsca pielgrzymkowego i pojawiają się wskazówki dotyczące uczestnictwa w nabożeństwach, przy czym podkreślane jest podobieństwo kalwarii w Wambierzycach do wzgórza w Jerozolimie:

17.

Jak v Jeruzalémě

byl Ježíš umučený, tak je Vambeřicích, tak je Vambeřicích všecko vystavený.

18.

To se mně tam libí, ten vrch Kalvárie, že tolik poutníku, že tolik poutníku $\mathrm{k}$ sobě přitahuje.

19.

$\mathrm{Na}$ tom vrchu je plac, co by moh'projíti umučení Páně, umučení Páně sobě rozjímati.
17.

Jako w Jeruzalem

Jezusa męczono, tak jest w Albendorfie, tak jest w Albendorfie wszystko wystawiono.

18.

Tam jest wielce sławna góra Kalwaryja, że wiele pątników, że wiele pątników na nią się ściągają.

19.

$\mathrm{Na}$ téj górze jest plac, co może obchodzić, mękę Jezusową, mękę Jezusową w kaplicach nawiedzić.

W zakończeniu pieśni pojawia się opis innego pobliskiego miejsca pielgrzymkowego, a mianowicie Barda Śląskiego, dokąd pielgrzymi wyruszali często z Wambierzyc:

39.

U Varty na hoře jest křižová cesta, pěkně spořádaná, pěkně spořádaná, na hoře kaplička.

40.

V té kapličce obraz

Panenka Maria, tam se poutníčkové, tam se poutníčkové modlejí horlivě.
39.

U Warty na górze jest krzyżowa droga, pięknie sporządzona, pięknie sporządzona na górze kaplica.

40.

W téj kaplicy obraz Panienki Maryi, kędy pątniczkowie, kędy pątniczkowie, modlą się gorliwie.

Również w tym przypadku tłumaczenie jest bardzo uproszczone. W wersji polskiej natrafiamy na bohemizmy, np. „zaniechawam” (cs. zanechávám, pl. pozostawiam), „porząd” (cs. pořád, pl. ciągle). W polskiej pieśni, w przeciwieństwie 
do czeskiej, używa się dodatkowo niemieckiej nazwy miasta Albendorf (Matka Boska pojawia się tu jako „Matka Albendorfska”).

Kolejnym przykładem paraleli jest para pieśni o incipitach „Sem, sem, poutníčkové, všickni pospěšte” oraz „Sam, sam, pontniczkowie, wszyscy pośpieszcie”. W środowisku czeskojęzycznym pojawia się ona od początku XIX w. jako pieśn do Matki Boskiej z Frydka ${ }^{11}$ oraz jako uniwersalna pieśn maryjna ${ }^{12}$. Z kolei w wersji polskojęzycznej jest udokumentowana w drukach z drugiej połowy XIX w. jedynie jako uniwersalna pieśn maryjna. Stanowi ona rodzaj hymnu pochwalnego z podmiotem zbiorowym, w którym Matka Boska jest czczona przez pielgrzymów, uczniów niebieskich i chóry anielskie oraz śpiewające dla niej „cztery strony świata”:

3 .

Všecky čtyry díly celého světa, prozpěvujte chvály

po všecka léta, anjelské Zdrávas, at' jest libý hlas, zdráva bud', Maria Frýdecká, od nás.

4 .

$\mathrm{V}$ povětři zpívejte ave, nebeští žáčkové, zpívejte salve, anjelské Zdrávas, at’ jest libý hlas, zdráva bud', Maria Frýdecká od nás.
3 . Wszystkie cztery części tego to świata wyśpiewujcie chwałę po wszystkie lata, zaśpiewajmy: Zdrowaś, ten to anielski głos, zdrowaś bądź, Maryja, tysiącroć od nas.

4 .

W powietrzu ptaszkowie śpiewajcie Pannie, niebiescy zaczkowie zaśpiewajcie salve, zaśpiewajmy: Zdrowaś, ten to anielski głos, zdrowaś bądź, Maryja, tysiącroć od nas.

W zakończeniu czeskiej wersji pojawia się wezwanie do pielgrzymowania, skierowane do pątników z Czech, Moraw i Słowacji (ówczesne Węgry), które przejęto z innej czeskiej pieśni „Ach, radostná chvíle, nemeškej již dýle”. Wersja polska ma odmienny finał jako pieśń uniwersalna, w której wezwanie zostaje skierowane ogólnie do czcicieli Matki Boskiej. W tym przypadku zmienia się też podmiot przemawiający - głos zabiera tu sama Matka Boska:

17.

Pojd' te sem, Čechové, Uhři, Moravci, Matičku Kristovu pozdravte všickni, budiž pozdravená, ode všech uctěná, od nás, svých ctitelův, Matko Kristova, Amen.
18.

Pójdźcie sam, najmilsi moi czciciele, Matkę Chrysta Pana pozdrowić wiernie, zaśpiewajmy: Zdrowaś, ten to anielski głos, zdrowaś bądź, Maryja, tysiącroć od nas. Amen.

10 Sześć pieśni. Pieśń o Najświętszéj Pannie Maryi, 1863, Mikołów, Teofil Nowacki, Biblioteka Śląska, sygn. BŚ SLM 214426 I.

11 Nábožná píseñ k Panně Marii Frýdecké, 1. poł. XIX w., Skalice, Moravské zemské muzeum, Brno, sygn. MZM ST 327 (cytowane dalej fragmenty pochądzą z tego druku).

12 Nábožná píseň k Panně Marii, 1813, Litomyšl, Vlastivědné muzeum, Šumperk, sygn. H 7065. 
Podobnie jak w poprzednich pieśniach, również tu mamy przykłady dosłownego tłumaczenia, np. czeskie słowo nemeškej (pl. nie spóźnij się) tłumaczone jest jako „nie mieszaj” (cs. nemíchej). W polskim tekście pojawia się też kuriozalne określenie Matki Boskiej - „śmierci godzinko” (cs. smrti hodinko) zamiast pierwotnego „, smrti hodince”, czyli „w śmierci godzince”. Polski tekst zawiera bohemizmy: Rodziczka (cs. Rodička), Maciczka (cs. Matička), „libeznie” (cs. líbezně, pl. słodko), litujcie (cs. litujte, pl. żałujcie). Na podstawie powyższych faktów możemy założyć, że pieśn została przetłumaczona z języka czeskiego na polski.

Podobne paralele można znaleźć nie tylko wśród pieśni maryjnych, ale też wśród pieśni o świętych. Za przykład może posłużyć para utworów do św. Anny: wersja czeska zaczyna się od słów „Já jsem si vyvolil za ochranu bábu Krista Pána, svatou Annu”13 i jest udokumentowana w drukach z drugiej połowy XVIII w., a jej polski odpowiednik ma incipit „Ja sobie wybrałem za obronę babkę Chrystusa, Świętą Annę" ${ }^{{ }_{14}}$ i pojawia się w publikacjach z drugiej połowy XIX w. Warto dodać, że w obiegu czeskojęzycznym incipit i referent tej pieśni wykorzystane zostały również $\mathrm{w}$ śpiewanym na tę samą melodię utworze przeznaczonym dla sanktuarium w Mariazell ${ }^{15}$. W pieśni do św. Anny wyeksponowany jest motyw pokonywania trudności podczas pielgrzymowania:

\section{4}

Byt̉ bych pod střechou byl, neb na cestě, v lesích, neb pustinách, v každém místě strach, bázeň na zemi, neb na moři, necht̉ se na mě valí, neumoří: necht' se jak se mnou děje, ty, svatá Anno, jsi má naděje.
4 . Bym też był na morzu, albo w lesie, na górach, pustyniach, albo w mieście, strachów morskich nie boję się, choć się na mnie zwalą, zachroni mnie: niech się jak chce ze mną dzieje, w tobie, Święta Anno, mam nadzieję.

Wyraźnie zaznaczone są też motywy uciekania się pod obronę świętej oraz passusy lamentacyjne, w których św. Anna pozostaje niewzruszoną nadzieją dla pielgrzyma doświadczającego smutku, nieszczęścia, niedostatku, choroby, biedy, wstydu, hańby czy omamionego bogactwem lub odrzuconego przez przyjaciół.

5 .

Bude-li mě bída, nouze trápit, anebo bohatství k sobě vábit, osidla svět svoje, když nalíčí, hanba neb potupa mne obklíčí: necht' se jak se mnou děje, ty, svatá Anno, jsi má naděje.
5.

Będzie-li mnie bieda, nędza trapić, lub też i bogactwo ku sobie wabić, świat swoje marności ukazywać, samo potępienie następować: niech się jak chce ze mną dzieje, w tobie, Święta Anno, mam nadzieję.

13 Mocná náděje. Svaté potěšení nejmilejší Matky Boží Anny svaté, všem věrným ctitelưm v kapli v Drozdovicích blíž města Prostějova na oltár̆i představené roku 1756, 1784, Olomouc, Slezské zemské muzeum, Opava, sygn. PPB 5/62/128.

14 Pieśń o Świętej Annie, 1859, Mikołów, Teofil Nowacki, Biblioteka Śląska, sygn. BŚ SLM 212196 I.

15 Píseň nábožná o blahoslavené Panně Marii Cellenské, pocz. XIX w., Těšín, Karol Prochaska, Muzeum Těšínska, Těšín, sygn. H-8613. 
Jestli mne veškeren svět opustí,

Anna, Matka chudých neopustí, necht̉ mne tupí, haní, jak kdo chce sám, v ní já mou jedinkou vždy schránku mám: necht’ se jak se mnou děje, ty, svatá Anno, jsi má naděje.
6.

Jeśli mnie obłudny świat opuści, Anna, Matka moja nie opuści, niech mnie jako chce prześladuje, Święta płaszczem mnie okryje: niech się jak chce ze mną dzieje, w tobie, Swięta Anno, mam nadzieję.

W polskiej wersji pieśni pojawia się znaczna liczba bohemizmów, np.: wywolił (cs. vyvolil, pl. wybrał) czy trapić (cs. trápit, pl. gnębić), co wskazywałoby na to, że pierwowzorem jest tekst czeski. Warto przy tym dodać, że w języku polskim istnieje wariant o długości porównywalnej z pieśnią czeską, ale natrafiamy też na tekst wyraźnie rozszerzony (27 strof), uzupełniony o passusy panegiryczno-błagalne oraz kilka fragmentów z opowieściami na temat życia św. Anny i Matki Boskiej ${ }^{16}$.

\section{Tłumaczenia czeskich pieśni religijnych w zbiorze Jana Kupca}

Dziś nie sposób już przeprowadzić rekonstrukcji okoliczności towarzyszących powstaniu konkretnych przekładów. Możemy się jedynie domyślać, że do tłumaczeń dochodziło np. podczas spotkań wiernych w trakcie pielgrzymek do miejsc kultu religijnego. $\mathrm{W}$ próbach wyjaśnienia procesu językowych adaptacji interesujących nas utworów cenną wskazówkę może stanowić ciekawe źródło polskiego pochodzenia, którym jest rękopiśmienny zbiór pieśni religijnych spisany przez pochodzącego z Łąk na Śląsku Jana Kupca (1841-1909). Był on zbieraczem pieśni ludowych i religijnych, poetą o regionalnym znaczeniu oraz śpiewakiem intonującym pieśni podczas pielgrzymek. Jak podaje ksiądz Jan Kudera, Kupiec udawał się na poszukiwanie pieśni nie tylko w najbliższe okolice, ale także na Morawy (Myszor, Burzywoda 1982: 243). Zebrane przez niego pieśni zostały opublikowane w opracowaniu Jana Myszora i Urszuli Burzywody (1982), którzy jednak nie podali konkretnych lokalizacji pochodzenia poszczególnych zapisów. Należy przy tym zauważyć, że choć część ze zgromadzonych tutaj tekstów znamy także z XIX-wiecznych polskich druków kramarskich, to jednak zbiór ten nie był dotąd porównywany z czeskimi pieśniami religijnymi, mimo że sami redaktorzy stawiają hipotezę, iż niektóre utwory mogły posiadać czeski pierwowzór. Jednym z celów prowadzonych przeze mnie badań było zatem przeanalizowanie owych materiałów w kontekście repertuaru czeskiego oraz znalezienie pierwotnych wersji poszczególnych utworów.

W wyniku przeprowadzonych analiz okazało się, że większość spisanych przez Kupca pieśni posiada czeski pierwowzór, i udało się zidentyfikować następujące paralele:

1. „Obwesel serce moje, niekwil, niemiej żałości” (według rękopisu pieśń przeznaczona dla Kalwarii Zebrzydowskiej); pierwowzór czeski „Obvesel se, srdce

16 Pieśń o Świętej Annie, 2. poł. XIX w., Bielsko, Karol Prochaska, Moravské zemské muzeum, Brno, sygn. MZM ST 1798. 
moje, nekvíl, neměj žalosti” (w obiegu czeskojęzycznym przeznaczona jest dla Vranova ${ }^{17}$.

2. „Cóż ja mam za trapieni, gdzie najde pocieszeni” (Kalwaria Zebrzydowska); pierwowzór czeski „Co já mám za trápení, kde najdu potěšení” (Mariazell, Šaštín, Drahov i Kojetín) ${ }^{18}$.

3. „Żaden nie wie, co jest łaska, Maryja, Maryja” (Częstochowa); pierwowzór czeski „Žádný neví, co jest láska, kdo ji nezkusil” (Marianka na Słowacji, Częstochowa) ${ }^{19}$.

4. „Ku komuż sie uciec mamy, jak k Pannie Maryi” (pieśń nieprzypisana do żadnego miejsca pielgrzymkowego); pierwowzór czeski „Ke komuž se utéct máme, než k Panně Marii” ${ }^{20}$.

5. „Słuneczko zaszło pójdziemy spaci” (pieśń nieprzypisana do żadnego miejsca pielgrzymkowego); pierwowzór czeski „Slunéčko zašlo, půjdeme spáti” (Suchdol, Žarošice) $)^{21}$.

6. „Zasmuceni na tem świecie, każ pójdziemy” (pieśń nieprzypisana do żadnego miejsca pielgrzymkowego); pierwowzór czeski „Na tom světě zarmouceným kam půjdeme” (Křtiny) ${ }^{22}$.

Czeskiego wariantu nie znalazłam jedynie w przypadku pieśni „Witaj Pani, my poddani nisko kłaniamy" (w rękopisie przeznaczona dla sanktuarium Gidlach) oraz pieśni „Wspomnij na najświętszą Pannę, tę Częstochowską” (Częstochowa).

Bardzo ciekawe wnioski pojawiły się też w wyniku dalszego porównywania zapisów Kupca z polskimi drukami kramarskimi, w których udało mi się odnaleźć trzy z wymienionych powyżej pieśni. Kiedy zestawimy czeski pierwowzór, wersję rękopiśmienną i polski druk kramarski, okaże się, że warianty Kupca są zazwyczaj bezpośrednimi przejęciami z czeskiego i pojawiają się w nich dosłowne tłumaczenia, które często nie mają sensu. Z kolei teksty obecne w polskich drukach kramarskich są pozbawione elementów gwarowych oraz bezsensownych słów i bardziej starannie zredagowane. Sytuację taką dobrze zilustruje

17 Píseñ nová k Panně Marii Svatovranovské, všem věrným poutníkưm na světlo vydaná, 1761, b. m., Moravské zemské muzeum, Brno, sygn. MZM ST 1660.

18 Píseň nová k Panně Marii Cellenský, poł. XVIII w., Kutná Hora, Jan Šleret, Vlastivědné muzeum v Olomouci, sygn. E 17993; Píseň nová k Panně Marii Šaštínské, 1. poł. XIX w., Těšín, Karel Procházka, Muzeum Těšínska, sygn. S 6872-18; Písen̆ nová k Panně Marii Svatokojetínské, 1772, Olomouc, Přerov, sygn. J 680.

19 Nábožná píseň o blahoslavené Panně Marii Tálské, ku potěšení všem poutníkům na světlo vydaná, 1. poł. XIX w., Moravské zemské muzeum, Brno, sygn. MZM ST 328; Píseñ nová ke cti a chvále blahoslavené Panny Marie Častochovské složená, 1751, Olomouc, Vlastivědné muzeum, Olomouc, sygn. VMO 19601.

20 Píseñ velmi horlivá, 1711, Olomouc, Vlastivědné muzeum, Olomouc, sygn. E 12557.

21 Pobožná píseň večerní v čas putování na milostné místo Marie Suchdolské, koniec XVIII w., Olomouc, Moravské zemské muzeum, Brno, sygn. MZM ST 1687; Píseñ večerní o blahoslavené Panně Marii Žarošické v čas putování, 1. poł. XIX w., b. m., Muzeum Beskyd, Frýdek-Místek, sygn. FM 11394.

22 Píseñ nová k Panně Marii Svatokřtinské, 2. poł. XIX w., Jindřichův Hradec, Jihlava, sygn. konv. 13, p. 21. 
zestawienie fragmentów zapisanej przez Kupca pieśni pielgrzymkowej „Słuneczko zaszło, pójdziemy spaci”, z jej odpowiednikami w postaci wspomnianej wcześniej czeskiej pieśni kramarskiej „Slunečko zašlo, půjdeme spáti” oraz z pieśnią z polskiego druku kramarskiego „Słoneczko zaszło, pójdziemy już spać” (z drugiej połowy XIX w.) ${ }^{23}$. Zarówno w wersji polskojęzycznej, jak i czeskojęzycznej utwór bywał często drukowany z uwagą „pieśń na dobranoc” (cs. píseñ na dobrou noc).

\begin{tabular}{|c|c|c|}
\hline (druk czeski) & (zapis Kupca) & (druk polski) \\
\hline $\begin{array}{l}4 . \\
\text { Panenko vzácná, } \\
\text { jasná dennice, } \\
\text { bud' všech přítomných } \\
\text { opatrovnice. }\end{array}$ & $\begin{array}{l}4 \cdot \\
\text { Panienko zacna, } \\
\text { nasza donico, } \\
\text { bądź wdycki przy nas, } \\
\text { opatrownico. }\end{array}$ & \\
\hline $\begin{array}{l}5 . \\
\text { Když budem' spáti, } \\
\text { rač při nás státi, } \\
\text { Matko s Ježíšem } \\
\text { opatrovati. }\end{array}$ & $\begin{array}{l}5 . \\
\text { Gdyż będę spaci, } \\
\text { racz przy nas staci, } \\
\text { Matko z Jezusem } \\
\text { opatrowaci. }\end{array}$ & $\begin{array}{l}4 . \\
\text { Gdy będziemy spać, } \\
\text { racz nas ratować, } \\
\text { Maryja z Jezusem, } \\
\text { raczcie przy nas stać. }\end{array}$ \\
\hline $\begin{array}{l}6 . \\
\text { Ten za stastného } \\
\text { se vždy nazývá, } \\
\text { kdo v jménu jejím } \\
\text { rád odpočívá. }\end{array}$ & $\begin{array}{l}6 . \\
\text { Ten za szczęsnego } \\
\text { być się nazywa, } \\
\text { kto w imię jego } \\
\text { rad odpoczywa. }\end{array}$ & $\begin{array}{l}6 . \\
\text { Ten to szczęśliwy } \\
\text { być się nazywa } \\
\text { który to to z Maryją } \\
\text { rad odpoczywa }\end{array}$ \\
\hline
\end{tabular}

Jest to pieśń maryjna, którą pątnicy śpiewali przed pójściem spać, kiedy dotarli już do celu swojej pielgrzymki. W dalszej części tekstów pojawiają się charakterystyczne formuły, za pomocą których Matka Boska, udziela pielgrzymom swojego błogosławieństwa:
(druk czeski)
(zapis Kupca)
(druk polski)
12.
12.
Dobrou noc ti mé
Dobrą noc ci me
11. srdce vinšuje, Matko z Zarošic, serce winszuje, Maciczko w zazdrości již spáti bude. niż spaci będę.
Dobra noc tobie z serca winszuje, o Matko w obronę twoję się daję.
13.
13.
Mé milé děti, půjdete spáti, že mně dobrou noc chcete dávati.
Me miłe dzieci, pujdziecie spaci, że wy mnie dobrą noc chcecie dawaci.
12.
Me miłe dzieci, gdyż pójdziecie spać, ja wam też na tę noc, dobrą noc chcę dać.

23 Sześć pieśni Pannie Maryi. Pieśń na dobra noc Najśw. Pannie Maryi, 1858, Teofil Nowacki, Biblioteka Śląska, sygn. BŚ SLM 213455 I. 
14.

Tak vás na tu noc chci požehnati, byste radostně dnes mohli spáti.
14 .

Tak was tej nocy chcę pożegnaci, abyście radośnie mogli przespaci.
13.

Ja was na tę noc chcę też pożegnać, abyście zaś zdrowo mogli jutro wstać.

Widzimy, że tekst Kupca zawiera szereg bohemizmów leksykalnych i słowotwórczych, np. pospołu (cs. pospolu) czy bezokoliczniki zakończone na -ci (dawaci, spaci), które nie pojawiają się już w wersji drukowanej. Można też stwierdzić, że w wariantach Kupca mamy do czynienia z tłumaczeniem dosłownym, w którym prawdopodobnie starano się zachować odpowiednią liczbę sylab w wierszu, ale zarazem pojawiają się różne przypadki ewidentnego niezrozumienia tekstu czeskiego. Prowadzi to do użycia zupełnie bezsensownych sformułowań, np. „Matko z Žarosic” przetłumaczono jako „Maciczko w zazdrości”, co po czesku brzmiałoby „Matičko v závisti“, natomiast określenie „jasná dennice” (jasna jutrzenko) to w rękopisie Kupca „nasza donico”.

Drugim przykładem, który chciałabym poddać dokładniejszej analizie, jest pieśń o inicpicie „Ku komuż się uciec mamy” (Pieśń o Pannie Maryi). W wersji czeskojęzycznej najstarszy przekaz jest udokumentowany w przywołanym powyżej druku z początku XVIII w. Znaleziona przeze mnie polskojęzyczna wersja drukowana pochodzi z drugiej połowy XIX w. ${ }^{24}$. W żadnym ze znanych mi źródeł pieśn nie pojawia się $\mathrm{z}$ odniesieniem do jakiegoś konkretnego miejsca pielgrzymkowego. Jest to utwór o charakterze panegiryczno-błagalnym z podmiotem zbiorowym, oparty na eksklamacjach skierowanych do Matki Boskiej i Chrystusa. Ciekawa jest tu prośba o ochronę przed wrogami, którymi są Turcy, Tatarzy i poganie oraz bliżej nieokreśleni przeciwnicy chrześcijaństwa („křestany protivnými”), a także przed fałszywymi radami („radami falešnými”). Istotne wydaje się zwłaszcza to, że w polskiej wersji drukowanej te motywy zostały pominięte, a w zamian możemy w tym miejscu przeczytać prośbę o ochronę ogniska domowego. W czeskiej pieśni pochodzącej z okresu baroku niebezpieczeństwo tureckie było aktualne; wariant Kupca jest tu wierny pierwowzorowi, jednak już wydawca polskiego druku z XIX w. potraktował ten motyw jako anachronizm i pominął go.

$\begin{array}{lll}\text { (druk czeski) } & \text { (zapis Kupca) } & \text { (druk polski) } \\ \text { 11. } & 11 . & 9 . \\ \text { Čárům, kouzlům } & \text { Czarom, gusłom } & \text { Czarom, gusłom } \\ \text { všem d'ábelským, } & \text { tém diabełskim, } & \text { tém diabełskim, } \\ \text { Maria, Maria! } & \text { Maryja, Maryja, } & \text { Maryja, Maryja, } \\ \text { nedej škodit } & \text { nie daj szkodzić } & \text { nie daj szkodzić } \\ \text { slouhám tvým, } & \text { sługóm twym, } & \text { sługom Boskim, } \\ \text { ó Ježíš, Maria! } & \text { o Jezus, Maryja. } & \text { o Jezus, Maryja, } \\ & & \text { Bądźże od nas } \\ & & \text { pozdrowiona, } \\ & & \text { Panienko Maryja. }\end{array}$

24 Trzy pieśni nowe o Najświętszej Pannie Maryi. Pieśń II., 2. poł. XIX w. Mikołów, Juliusz Nowacki, Biblioteka Śląska, Katowice, sygn. BŚ SLM214615 I. 
12.

Ochraňuj císaře pána, Maria, Maria!

bud' jeho silná obrana, ó Ježíš, Maria!
12.

Ochraniaj króla naszego, Maryja, Maryja, bądź silna obrona jego, o Jezus, Maryja.
13.

Přede všemi nepřáteli, Maria, Maria!

Turky, Tatary, pohany, ó Ježíš, Maria!
13.

Przede wszemi nieprzacieli, Maryja, Maryja, Turki, Tatary, pogany, o Jezus, Maryja.
10.

Ognia ostrzec

domowego, Maryja, Maryja, obroń, Panno z nas każdego, o Jezus, Maryja. Bądźże od nas pozdrowiona, Panienko Maryja.

11.

Raczże bronić teraźniejszego, Maryja, Maryja, cesarza naszego chrześcijańskiego, o Jezus, Maryja. Bądźże od nas pozdrowiona, Panienko Maryja.
14 .
14.
Před křest’any
Przed krześciany przeciwnemi, protivnými,
Maria, Maria!
Maryja, Maryja.
przed radami
před radami
fałesznemi,
falešnými,
o Jezus, Maryja.
ó Ježíš, Maria!

Warto zauważyć, że do charakterystycznej zmiany dochodzi też w prośbie o wzięcie w opiekę władcy. W czeskiej i polskiej wersji drukowanej jest to cesarz, podczas gdy u Kupca mamy króla ( $w$ innych czeskich wydaniach pojawia się też królowa). Interesujące jest również porównanie formuł błagalno-modlitewnych odnoszących się do szlachty i duchowieństwa, w których pojawiają się znaczące różnice:

$\begin{array}{lll}\text { (druk czeski) } & \text { (zapis Kupca) } & \text { (druk polski) } \\ \text { 15. } & \text { 15. } & \\ \text { Uděl rozum } & \text { Udziel rozum } & \text { Udziel rozum } \\ \text { všechněm pánům, } & \text { wszyckim panom, } & \text { wszystkim panom, } \\ \text { Maria, Maria! } & \text { Maryja, Maryja, } & \text { Maryja, Maryja, } \\ \text { vrchnostem, } & \text { wiersznosciąm } & \text { daj nam twe } \\ \text { taky všem stavům, } & \text { i wszyckim stawom, } & \text { błogowsławieństwo, } \\ \text { ó Ježís, Maria! } & \text { o Jezus, Maryja. } & \text { o Jezus, Maryja. } \\ & & \text { Bądźże od nas } \\ & & \text { pozdrowiona, } \\ & & \text { Panienko Maryja. }\end{array}$


16.

Dejž duchovním rozum správcům, Maria, Maria! at’ nás vedou $\mathrm{k}$ věčným stánům, ó Ježíš, Maria!
16.

Daj duchownym rozum, sprawę, Maryja, Maryja, aż nas wiedą k wiecznem rzeczą, o Jezus, Maryja.
13.

Podpieraj i duchowieństwo, Maryja, Maryja, daj nam twe błogosławieństwo, o Jezus, Maryja, Bądźże od nas pozdrowiona, Panienko Maryja.

Tekst pieśni z rękopisu Kupca jest wierny wersjom czeskim, stanowiąc ich dosłowne tłumaczenie na język polski, zawiera przy tym szereg bohemizmów i elementów gwarowych, np. dufający (cs. doufající, pl. mający nadzieję), Maciczka (sc. Matička), Rodziczka (cs. Rodička), przytomna (cs. přítomná, pl. obecna), stroić (sc. strojit, pl. przygotowywać się do odejścia) itp. Natomiast wersja z polskiego druku kramarskiego różni się znacząco, nie tylko dodanym dwustrofowym referentem, ale też sposobem tłumaczenia oraz zmianami w zakresie treści.

Ostatnim przykładem z zapisów Kupca, na który trzeba zwrócić uwagę, jest pieśń o incipicie „Żaden nie wie, co jest łaska, Maryja, Maryja“. W środowisku czeskim jest ona udokumentowana przywołanymi powyżej drukami kramarskimi z drugiej połowy XVIII i XIX w. W jej tekście pojawiają się określenia zapożyczone z XVII-wiecznej miłosnej poezji dworskiej (salve, fant, vale); ponadto zawiera ona wiele słowotwórczych morawizmów (np. moja, svoju) i zwrotów potocznych (np. tvůj milej). Porównując czeski pierwowzór z zapisem Kupca, możemy zauważyć, że zachowano tu część wspomnianych wyżej słów pochodzących z poezji dworskiej, ktore z kolei w polskim druku kramarskim zostały całkowicie usunięte ${ }^{25}$.

$\begin{array}{lll}\text { (druk czeski) } & \text { (zapis Kupca) } & \text { (druk polski) } \\ \text { 6. } & \text { 6. } & \text { 6. } \\ \text { Jenom sobě, ó Maria, } & \text { Tylko sobie, o Maryja, } & \text { Tylko sobie, } \\ \text { dnes to pamatůj, } & \text { Maryja, Maryja, } & \text { o Maryja, Maryja, } \\ \text { že ty musís býti moja } & \text { tyle wyjednam } & \text { tyle wyjednam, } \\ \text { a já budu tvůj, } & \text { że ty będziesz mą patrunką, że ty będziesz mą patronką, } \\ \text { srdce ti na fant dávám, } & \text { Maryja, Maryja, } & \text { Maryja, Maryja, } \\ \text { že upřímnou lásku mám, } & \text { jać sie oddawam, } & \text { ja-ć się oddawam, } \\ \text { ti za život duše světlo } & \text { serce na fant oddawam, } & \text { gdyż przy tobie łaskę mam } \\ \text { oka mého dám. } & \text { gdyż przy tobie łaskę mam, i tobie szczerze ufam, } \\ & \text { ty żywocie dusz światłości, ty żywocie dusz światłości, } \\ & \text { Maryja, Maryja, } & \text { Maryja, Maryja, } \\ & \text { jać sie porączam } & \text { ja-ć się poruczam. }\end{array}$

Podsumowując, można stwierdzić, że Jan Kupiec, będąc przewodnikiem i śpiewakiem pielgrzymkowym, sam tłumaczył czeskie pieśni, chcąc w ten sposób poszerzyć repertuar utworów wykorzystywanych podczas pielgrzymek. Prawdo-

25 Sześć pieśni o Najświętszej Pannie Maryi, 2. poł. XIX w., Mikołów, Juliusz Nowacki, Biblioteka Śląska, Katowice, sygn. BŚ SLM 214515. 
podobnie nie miał on dostępu do wydawnictw z polskimi tekstami, dlatego decydował się, by samodzielnie przekładać pieśni, które być może usłyszał od czeskich pielgrzymów lub zdobył w postaci czeskojęzycznych druków kramarskich. Kupiec nie znał dobrze języka czeskiego, stąd w jego tłumaczeniach błędy i niekiedy absurdalne wręcz pomyłki. Porównując jego zapisy z polskimi drukami kramarskimi, można stwierdzić, że w tych ostatnich pojawiają się inne tłumaczenia, w których dodatkowo dokonano uaktualnienia tekstów.

\section{Rola drukarni w procesie przejmowania pieśni religijnych}

$\mathrm{W}$ procesie wzajemnego przejmowania pieśni na pograniczu czesko-polskim nie można pominąć roli regionalnych wydawców i drukarzy popularnej literatury religijnej, którzy z powodów komercyjnych również byli zainteresowani poszerzeniem oferty swoich publikacji. Ze względu na bliskość językową mogli oni czerpać nie tylko z własnego repertuaru pieśni, ale także z pieśniowych zasobów swoich sąsiadów. Niekiedy informacja o tłumaczeniu utworu znajdowała odzwierciedlenie w samym tytule publikacji. Jako przykład można podać druk Pieśń nowa o najświętszej Pannie Maryi Kalwaryjskiej z morawskiego języka na polski przełożonej, wydany w drugiej połowie XIX w., który odnotowany jest w bibliografii Estreichera (1876: 387 ). Na podobne przykłady zwraca uwage również Stanisław Dobrzycki, który wymienia bliżej nieokreślony hymn maryjny wydany w drukarni Pisza w Bochni około 1860 r. zawierający przypis „z morawskiego na polski tłumaczony“ oraz hymn do św. Jana Nepomucena z przypisem „Z czeskiego na polski tłumaczony“ (Dobrzycki 1930: 66-67).

Interesujące jest zwłaszcza to, że drukarnie na Śląsku Cieszyńskim w kilku udokumentowanych przypadkach wydawały czeską i polską wersję pieśni prawie jednocześnie. Przykłądowo, drukarnia Prochaski w Cieszynie wydała w ten sposób pieśni maryjne o incipitach „Když jsme přišli $k$ tobě, Královno, před tvůj zázračný obraz, Královno“ i „Gdyśmy przyszli do kościoła, Królowo, przed tak cudowny obraz twój, o Królowa“ ${ }^{{ }_{2} 6}$. Podobną praktykę można zauważyć w przypadku drukarni Franciszka Orła we Frydku, która opubilowała równolegle pieśń do Chrystusa o incipicie „Veliká to milost Boga otce byla“ i jej polski wariant „Wielka to miłość Boga Ojca była“ ${ }^{{ }^{27}}$. Należy zaznaczyć, że przejmowanie przez wydawców i drukarzy obcojęzycznego repertuaru nie dotyczyło tylko omawianych tu pieśni pielgrzymkowych, ale także innych utworów o tematyce religijnej i świeckiej. Przykładowo, legenda pt. Pieśń marnotrawnym bednarzu, opisująca cud, jaki wydarzył się za wstawiennictwem Maryi, to w czeskim pierwowzorze Truchlivá píseñ o jednom marnotratném bečváři (Nyrkowski 1977: 296-299); powiązania czeskie ma także pieśń o żydowskich dzieciach (Mętrak 2017: 95).

26 Nová píseñ k Panně Marii. Z nèmeckého na polské, pak z polského na moravské preložená, pocz. XIX w., Tomáš Ferdinand Procházka, Přerov, sygn. J 2682; Pieśń o Najświętszéj Pannie Maryi, poł. XIX w., Bielsko, Karol Prochaska, Moravské zemské muzeum, Brno, sygn. MZM ST 1328.

27 Píseň o Umučení Pána Ježíše Krista, 2. poł. XIX w., Frydek, František Orel, Muzeum Beskyd, Frýdek-Místek, sygn. FM 12422 S; Pieśń o całej męce Pana naszego Jezusa Chrystusa, 2. poł. XIX w., Frydek, Franciszek Orzeł, Muzeum Beskyd, Frýdek-Místek, sygn. FM 11067 S. 
Warto dodać, że zjawisko czesko-polskich paraleli w publikacjach kramarskich nie ogranicza się do bezpośrednich tłumaczeń, ale polega także na tworzeniu różnych wersji tych samych historii opartych na wspólnym pierwowzorze niemieckim, ewentualnie łacińskim.

\section{Zakończenie}

W swoich rozważaniach starałam się pokazać możliwości wykorzystania pieśni publikowanych w drukach kramarskich do badań nad czesko-polskimi kontaktami literackimi. Prowadzone przeze mnie analizy dostarczają dowodów na zachodzącą w obu kierunkach wymianę repertuaru pielgrzymkowego, upowszechniającego się w XVIII i XIX w. Za najważniejsze dwa czynniki stymulujące tę wymianę można uznać komercyjne aspekty działania wydawców i drukarzy (poszukiwanie nowego repertuaru lub nowych odbiorców w celu zwiększanie zysków) oraz religijne aspekty działania pielgrzymów, a zwłaszcza przewodników/spiewaków pielgrzymkowych, którzy, tak jak Kupiec, na własną rękę próbowali poszerzać repertuar śpiewów. Wydawcy popularnej literatury religijnej na pograniczu czesko-polskim dzięki bliskości językowej czerpali nie tylko z repertuaru pieśni krajowych, ale także z pieśni sąsiadów. Możemy się też domyślać, że do włączenia obcych pieśni do lokalnej tradycji dochodziło wskutek spontanicznego przejmowania poszczególnych utworów w środowisku ludowym, szczególnie podczas spotkań pielgrzymów różnych narodowości w popularnych sanktuariach.

Moje badania wskazują na to, że w obiegu kramarskim i pielgrzymkowym zachodząca wymiana repertuaru pieśniowego nie wiązała się z wyraźnym procesem twórczym. Pieśni były przejmowane bez istotnych zmian, często tłumaczone niemal dosłownie, co skutkowało pojawianiem się niezgrabnych, nielogicznych, a niekiedy nawet bezsensownych zwrotów. Nie zmieniał się również ich charakter gatunkowy, ponieważ w XVIII i XIX w. forma pieśni pielgrzymkowych była już w przypadku obu literatur trwale ustalona. Wymieniano jedynie imiona patronów czy nazwy miejsc pielgrzymkowych, pojawiały się też niewielkie odchylenia znaczeniowe, jednak ogólna wymowa pieśni pozostawała ta sama. Jak wskazywałam, do przejmowania repertuaru między regionami czeskojęzycznymi i polskojęzycznymi dochodziło nie tylko na polu maryjnych pieśni pielgrzymkowych, ale także w przypadku pieśni o Chrystusie czy o świętych, które pod tym względem zasługują na osobne opracowanie.

Szczególnie istotne znaczenie ma fakt, że włączone do krajowego repertuaru pieśni pielgrzymkowe zaczynały żyć „własnym życiem” i w ramach obiegu kramarskiego w obu krajach dochodziło do powstawania kolejnych wariantów, tworzonych w odpowiedzi na konkretne potrzeby (np. lokalnych sanktuariów). Zjawisko to potwierdza przywołaną na wstępie tezę Oldřicha Sirovátki, wskazując na to, że badany repertuar funkcjonował zgodnie z zasadami obiegu tekstów folkloru, a zarazem $\mathrm{w}$ obie strony przekraczał nie tylko granice etniczne między narodami spokrewnionymi językowo i kulturowo, ale także granice między ustnością a piśmiennością i drukiem. 


\section{SPIS DWUJĘZYCZNYCH PIEŚNI PIELGRZYMKOWYCH}

Spis zawiera incipity 38 dwujęzycznych pieśni pielgrzymkowych zidentyfikowanych w trakcie badań $\mathrm{w}$ zbiorach wymienionych $\mathrm{w}$ przypisie $\mathrm{nr}$ 1. Literą „a” oznaczono incipity pieśni czeskich odnoszące się różnych miejsc pielgrzymkowych, literą „b” - odpowiednio warianty polskie.

1a Ach, mé milé potěšení, ó Matičko moje!

1b Ach, me miłe pocieszenie, o Matuchno moja

2a Co já mám za trápení, kde najdu potěšení tu Drahovskou / Kojetínskou Pannu Marii

Co já mám za trápení, kde najdu potěšení, to Cellenskou, archanjelskou Pannu Marii

Co já mám za trápení, kde najdu potěšení, Svatokřtinskou, ach, anjelskou Pannu Marii

Co já mám za trápení! kde najdu potěšení? tu Šaštínskou, archanjelskou Pannu Marii

Cóż ja mam za trapieni, gdzie najdę pocieszeni, Matkę Boską Kalwaryjską Pannę Maryją

Dobrý den, vinšujem tobě, ó Maria

Maryja Piekarska, Pani nasza

Horo krásná, spanilá, Svatokřtinská Maria

Horo krásná, spanilá, Starohorská Maria

Růže krásná, spanilá, Svatochlumecká Maria

Gwiazdo śliczna, wspaniała, Kalwaryjska Maryja

Gwiazdo śliczna, wspaniała, Częstochowska Maryja

Já jsem si vyvolil za ochranu Bábu Krista Pána, svatou Annu

Já jsem si vyvolil za ochranu Matičku Cellenskou, svatou Pannu

Jam sobie wyzwolił za obronę Babkę Chrystusa, Świętą Annę

K komuž se utécti máme než k Panně Marii?

Ku komóż się uciec mamy? ku Maryi? ku Maryi

Kam se mám smutný obrátit, Bůh na mne rozhněván

Gdzież się smutny mam obrócić, Bóg na mnie rozgniewan

Když jsme přišli k tobě, Královno, před tvůj zázračný obraz, Královno

Gdyśmy przyszli do kościoła, Królowo, przed cudowny obraz twój

Maria, Maria, nad slunce jasnější

Maryja, Maryja, nad słońce jaśniejsza

Maria, ochrana onat jest má sama

Maryja, obrona ona mocna sama

Marš, marš, mé srdce, na kalváriju, tam jest tvůj kvartýr, tam hříšní žiju

Marsz, marsz, me serce na kalwaryją, tam jest twój kwarter, tam grzeszni żyją

Na frýdecké hoře krásná pěkná růže přelíbezně voní

Na hostýnské hoře krásná pěkná růže přelíbezně voní

Na té křtinské hoře krásná pěkná růže přelíbezně voní

Na římovské hoře krásná pěkná růže přelíbezně voní

Na tej Jasnéj Górze krasne, piękne róże przelibeznej woni

Na tom světě zarmouceným kam půjdu

Zasmuceni na tem świecie, każ pójdziemy

Nejsvětější Rodičko, Matko Pána Ježíše

O najświętsza Rodzico, Matko Pana Jezusa 
15a Ó Maria, hledám tě dávný čas! nemohu tě najíti

15b O Maryja, szukam cię dawny czas, ach, nie mogę cię znaleźć

16a Ó Maria, moje radost, mé celé potěšení

16b O Maryja, moja radość, moje pocieszenie

17a Ó Maria, vzpomeň na mě, neboț nemám žádného

$17 \mathrm{~b}$ O Maryja, wspomnij na mnie, boć ja nie mam żadnego

18a Obvesel se, srdce moje, nekvil, neměj žalosti

18b Obwesel, serce moje, nie kwil, nie miej żałości

19a Plesej, mé srdce, radostí, pojd', poutníčku, s důvěrností

19b Skacz, moje serce, z radości, pójdź, pontniczku, do wieczności

$20 \mathrm{a}$

Pojd', pojd', mé srdce, na kalvárii, tam jest tvůj pobyt, tam hříšní žijou

Pospiesz, me serce, na kalwaryją, tam jest to miejsce, tam grzeszni żyją

Před věky zvolená, Panno Maria, nám za př́klad dána, Matičko milá

Překrásná růžička líbezně voní, má duše mé srdce dychtilo po ní

Přeradostná a milostná nastala nám hodina

Przeradosna a miłosna nastała nam godzina

Rozvíjej se kvítí, krásně svítí slunéčko

Rozwijaj się kwiecie, świeci słoneczko

Sem, sem, poutníčkové, všickni pospěšte

Sam, sam, pątniczkowie, wszyscy pośpieszcie

Slunéčko zašlo, půjdeme spáti

Slyšel jsem krásný hlas, Maria volá nás

27b Słyszałem śliczny głos, Maryja woła nas

Slyším hlas slavíčka v jednou oudolí, kteráž ta Matička v brněnském kraji Slyším hlas slavíčka v jednou oudolí, kteráž ta Matička v cellenském kraji Slyším hlas slavíčka v jednou oudolí, kteráž ta Matička v těšínském kraji Śpiewa mi słowiczek na rajskim dworze

Svatý Lukáš, maléř Boží, on maloval obraz Boží

Święty Łukasz ewanielista wymalował obraz czysto

Tisíckrát bud' pozdravena, ó Maria, Maria Tysiąckroć bądź pozdrowiona, o Maryja, 
33a Vesele, překrásně já zpívati budu

33b Vesele, překrásně já zpívati budu

34a Vinšované jara, ó nebeský ráji

34 b Winszowana wiosno, o niebieski raju

35a $\quad Z$ dalekéj jsme krajiny, nemáme my rodiny

35b Z dalekiej my krainy, nie mamy tu rodziny

36a Ze všech nejkrásnější já milou mám

36b Ze wszech najśliczniejszą ja miłą mam

37a Zdrávas budiž, ó Maria, nejdůstojnější!

37b Zdrowaś bądź dziś, o Maryja, najdostojniejsza

38a Žádný neví, co jest láska, kdo ji nezkusil

38b Żaden nie wie, co jest łaska, Maryja, Maryja

\section{BIBLIOGRAFIA}

Beneš, B. (1988). Funkcje pieśni kramarskich w literaturze popularnej. Literatura Ludowa, 32(1), 15-22.

Dobrzycki, S. (1930). Kolędy polskie a czeskie, ich wzajemny stosunek. Poznań: Poznańskie Towarzystwo Przyjaciół Nauk.

Dola, K. (2004). Pieśń kościelna pogranicza śląsko-morawskiego. W: J. Tutaj (red.), Pogranicze, kultura, religia (s. 273-278). Wałbrzych: WWSZiP.

Estreicher, K. (red.) (1876). Bibliografia polska XIX. stólecia. T. 3 (Ł-Q). Kraków: Akadamia Umiejętności.

Grochowski, P. (2016). Jarmark tradycji. Studia i szkice folklorystyczne. Toruń: Wydawnictwo Naukowe UMK.

Ivánek, J. (2017). Poznámky k vymezení pojmu kramářská píseň (s ohledem na tisky náboženské povahy). Listy filologické, 140, 201-230.

Ivánek, J., Malura, J. (2019). Horo krásná, spanilá! Poutní písně na Moravě (160o-1850). Brno: Host.

Ivánek, J., Malura, J., Olšovský, J., Schenková, M., Szturcová, M. (eds.) (2019). Pod ochranu tvou se utíkáme. Kult Panny Marie Čenstochovské v českém Slezsku na Moravě. Częstochowa-Ostrava: Wydawnictwo Naukowe Uniwersytetu im. Jana Długosza, Ostravská univerzita.

Kałuża, M. (1974). Pieśni religijne pochodzenia morawskiego i czeskiego na Ziemi Wodzisławskiej. Praca magisterska. Katowice: Uniwersytet Śląski.

Kafka, L. (2008). Líbezně nás volá, Matička Cellenská: Zobrazení Panny Marie v kramářských tiscích. In M. Holubová (ed.), Obrazy ženy v kramářské produkci (pp. 149-168). Praha: Etnologický ústav AV ČR.

Kolberg, O. (1966). Dzieła wszystkie. t. 4o. Mazury Pruskie. Wrocław, Poznań: Polskie Wydawnictwo Muzyczne.

Kosek, P., Slavický, T., Škarpová, M. (eds.) (2012). Fridrich Bridel: Jesličky. Staré nové písničky. Brno: Host.

Malura, J. (2010). Písně pobělohorských exulantů (1670-1750). Praha: Academia.

Mętrak, M. (2017). Językowy i kulturowy obraz Żyda w czeskich drukach kramarskich. Zeszyty Łużyckie, 51, 89-109.

Mętrak, M. (2018). Czeska twórczość kramarska - zarys zagadnienia. W: D. Dziadosz, A. Krzanowska (red.), Stowianie, kultura, język. Wybrane zagadnienia z języków, literatur i kultur słowiańskich i germańskich (s. 351-361). Szczecin: Wydawnictwo Naukowe Uniwersytetu Szczecińskiego. 
Myszor, J., Burzywoda, U. (1982). Pieśni pątnicze ze zbioru Jana Kupca. Śląskie Studia Historyczno-Teologiczne, 15, 243-271.

Nowak, A. (1996). Polsko-niemiecko-czeska pieśń religijna. Praca magisterska. Opole: Uniwersytet Opolski.

Nyrkowski, S. (red.) (1977). Karnawał dziadowski. Pieśni wędrownych śpiewaków (XIX-XX w.). Warszawa: Ludowa Spółdzielnia Wydawnicza.

Sirovátka, O. (1996). Srovnávací studie o české lidové slovesnosti. Brno: Akademie věd České republiky.

Sobotková, M. (2002). Studie z české a polské literatury. Pět století v historii česko-polských literárních souvislostí. Olomouc: Univerzita Palackého v Olomouci.

Sušil, F. (1860). Moravské národní písně. Brno: Karel Winiker.

Waliński, M. (1975). Tradycja i pieśń kramarska w Czechosłowacji. Literatura Ludowa, 19(4-5), 27-43.

Windakiewiczowa, H. (1908). Katalog pieśni polsko-morawskich. Materyały Antropologiczno-Archeologiczne i Etnograficzne, 10, 3-43. 